\title{
The millipede genus Cryptocorypha Attems, 1907 revisited, with descriptions of two new Oriental species (Diplopoda: Polydesmida: Pyrgodesmidae)
}

\section{Снова о многоножкках-диплоподах рода Cryptocorypha Attems, 1907 с описаниями двух новых ориентальных видов (Diplopoda: Polydesmida: Pyrgodesmidae)}

\author{
S.I. Golovatch \\ С.И. Головач
}

Institute for Problems of Ecology and Evolution, Russian Academy of Sciences, Leninsky prospekt 33, Moscow 119071 Russia. Институт проблем экологии и эволюции РАН, Ленинский проспект, 33, Москва, Россия.

KEY WORDS: Diplopoda, Cryptocorypha, taxonomy, new species, Laos, Thailand.

КЛЮЧЕВЫЕ СЛОВА: Diplopoda, Cryptocorypha, таксономия, новый вид, Лаос, Таиланд.

ABSTRACT. The largely Old World, tropical or subtropical diplopod genus Cryptocorypha Attems, 1907 is reviewed, with the following three new formal generic synonyms established: Carlodesmus Verhoeff, 1941, Cryptomauritius Verhoeff, 1941 and Sisyrodesmus Attems, 1912, all syn.n. Two species are newly synonymized: C. fungifer (Attems, 1953), comb.n. (= C. leleupi Golovatch, Nzoko Fiemapong et VandenSpiegel, 2017), and C. riparia (Carl, 1932), comb.n. (= C. lawrencei (Verhoeff, 1941)), both syn.n. Another two new species are described: C. bicolorata sp.n. from Laos and C. jaegeri sp.n. from northern Thailand. A provisional key is compiled to all 25 currently recognized species of Cryptocorypha, including two old congeners, C. tobana Chamberlin, 1945, from Sumatra, Indonesia and C. leia Chamberlin, 1945, from Java, Indonesia, based on a revision of their holotypes.

How to cite this article: Golovatch S.I. 2019. The millipede genus Cryptocorypha Attems, 1907 revisited, with descriptions of two new Oriental species (Diplopoda: Polydesmida: Pyrgodesmidae) // Arthropoda Selecta. Vol.28. No.2. P.179-190. doi: 10.15298/ arthsel. 28.2.01

РЕЗЮМЕ. Дан обзор диплопод в основном тропического рода Cryptocorypha Attems, 1907 с установленными тремя формально новыми родовыми синонимами: Carlodesmus Verhoeff, 1941, Cryptomauritius Verhoeff, 1941 и Sisyrodesmus Attems, 1912, все три syn.n. Предложены два новых видовых синонима: C. fungifer (Attems, 1953), comb.n. (= C. leleupi Golovatch, Nzoko Fiemapong et VandenSpiegel, 2017), и C. riparia (Carl, 1932), comb.n. (= C. lawrencei (Verhoeff, 1941)), оба syn.n. Описаны два новых вида: C. bicolorata sp.n. из Лаоса и $C$. jaegeri sp.n. из Северного Таиланда. Представлен предварительный ключ для всех 25 ныне признанных ви- дов рода Cryptocorypha, включая два старых вида, C. tobana Chamberlin, 1945, с Суматры (Индонезия) и C. leia Chamberlin, 1945, с Явы (Индонезия), на основе ревизии их голотипов.

\section{Introduction}

The mainly Old World, tropical or subtropical millipede genus Cryptocorypha Attems, 1907 has only recently been reviewed, rediagnosed and shown to comprise 21 species [Golovatch et al., 2017; Likhitrakarn et al., 2019]. The issue, however, needs to be revisited not only because of two new species to be described, but also to document a few new synonymies, to transfer two new congeners, and to revise the holotypes of another two old species.

\section{Material and methods}

The type series of both new Cryptocorypha were borrowed from and will be returned to the collection of the Senckenberg Naturmuseum, Frankfurt a.M. (SMF), Germany. The holotypes of two old species of R.V. Chamberlin were borrowed from the American Museum of Natural History (AMNH), New York and revised at the Museum of Comparative Zoology (MCZ) in Harvard, USA.

Colour pictures of the new species were most skillfully taken and stacked by Kirill Makarov (Moscow, Russia), whereas those of Chamberlin's congeners by Mrs Jennifer Trimble (MCZ).

\section{Taxonomy}

Cryptocorypha Attems, 1907

Type-species: Cryptocorypha stylopus Attems, 1907, Java, by monotypy. 
= Procoptodesmus Brolemann, 1920, synonymized by Golovatch et al. [2017].

Type-species: Procoptodesmus diffusus Brolemann, 1920, Tanzania, by original designation.

= Archandrodesmus Carl, 1932, synonymized by Hoffman [1977].

Type-species: Archandrodesmus areatus Carl, 1932, India, by original designation.

= Platykapelus Attems, 1938, synonymized by Hoffman [1977].

Type-species: Platykapelus ornatus Attems, 1938, Hawaii, by original designation.

= Cryptomauritius Verhoeff, 1941, syn.n.

Type-species: Cryptomauritius lawrencei Verhoeff, 1941, Mauritius, by monotypy.

= Ceyloncarlia Verhoeff, 1941, synonymized by Hoffman [1977].

Type-species: Archandrodesmus kandyanus Carl, 1932, Sri Lanka, by monotypy.

= Afrocorypha Loksa, 1967, the Republic of the Congo, synonymized by Golovatch et al. [2017].

Type-species: Cryptocorypha (Afrocorypha) nympha Loksa, 1967, by monotypy.

= Sisyrodesmus Attems, 1912, syn.n.

Type-species: Sisyrodesmus girafficeps Attems, 1912, Rwanda, by monotypy.

= Carlodesmus Verhoeff, 1941, syn.n.

Type-species: Archandrodesmus riparius Carl, 1932, India, by monotypy.

Among others, both Carlodesmus and Sisyrodesmus have long been circumscribed [Hoffman, 1977] as a group of genera deemed to be especially close to Cryptocorypha, but so far their synonymies have never been formalized. In addition, Hoffman [1977] correctly noticed that Cryptomauritius lawrencei Verhoeff, 1941, from Mauritius [Verhoeff, 1941], is fully identical to ?Archandrodesmus riparius Carl, 1932, from southern India [Carl, 1932], but he regarded this species sufficiently distinct from Cryptocorypha $(=$ Archandrodesmus) spp. at the generic level to warrant the recognition of Cryptomauritius as a separate genus [Hoffman, 1977, 1980]. However, because all of them clearly show basically the same somatic and gonopodal conformations (see a refined diagnosis below), they are treated here as a single large genus.

All species previously included in Cryptocorypha have recently been listed, with complete data on their distributions also provided [Likhitrakarn et al., 2019]. That listing is briefly repeated below and the species are arranged in alphabetic order: C. areata (Carl, 1932); C. bocal Golovatch, Nzoko Fiemapong et VandenSpiegel, 2017; C. chernovi Golovatch, Geoffroy et VandenSpiegel, 2013; C. diffusa (Brolemann, 1920); C. dimorpha Golovatch, Nzoko Fiemapong et VandenSpiegel, 2017; C. enghoffi Likhitrakarn, Golovatch, Strisonchai, Sutcharit et Panha, 2019, C. hoffmani Golovatch, Semenyuk, VandenSpiegel et Anichkin, 2011; C. japonica (Miyosi, 1957); C. kandyana (Carl, 1932); C. kumamotensis (Murakami, 1966); C. leia Chamberlin, 1945; C. leleupi Golovatch, Nzoko Fiemapong et VandenSpiegel, 2017; C. monomorpha Golovatch, Nzoko Fiemapong et VandenSpiegel, 2017; C. nympha Loksa, 1967; C. ornata (Attems, 1938); C. perplexa Golovatch et VandenSpiegel, 2015; C. spinicoronata (Zhang et Li, 1981); C. stylopus Attems, 1907 (the type species); C. tobana Chamberlin, 1945; and C. tuberculata (Carl, 1932). At least further two, apparently new, but yet undescribed species of Cryptocorypha have recently been recorded from Nepal [Golovatch, Martens, 2018].

With the above synonymization of Carlodesmus Verhoeff, 1941, Cryptomauritius Verhoeff, 1941 and Sisyrodesmus Attems, 1912 under Cryptocorypha, the following new transfers, as well as two new specific synonymies are warranted: C. riparia (Carl, 1932), comb.n. ex Carlodesmus; C. lawrencei (Verhoeff, 1941), comb.n. ex Cryptomauritius; C. riparia (Carl, $1932)=$ C. lawrencei $($ Verhoeff, 1941), syn.n.; C. coalita (Attems, 1953), C. fungifer (Attems, 1953) and C. girafficeps (Attems, 1912), all comb.n. ex Sisyrodesmus; C. fungifer (Attems, 1953) = C. leleupi Golovatch, Nzoko Fiemapong et VandenSpiegel, 2017, syn.n., these two latter species coming even from the same type locality: Itombwe, the Democratic Republic of the Congo.

Another genus, Aporodesminus Silvestri, 1904, with only one accepted species, A. wallacei Silvestri, 1904 (= Cryptocorypha napoleonis Attems, 1907, synonymized by Hoffman [1977]), almost fully fits in the diagnosis of Cryptocorypha, particularly its gonopodal traits. Like $C$. ornata, A. wallace i is nearly pantropical and semi-aquatic, and it is also widely scattered across the islands and archipelagos of the Atlantic and Pacific oceans, including a creek at Sydney, Australia (see Adis et al. [1998]). Superficially, A. wallacei differs strongly enough from Cryptocorypha in the absence of ozopores and the related reduction of the number of lateral lobulations on all postcollum paraterga to three, while the gonopodal telopodites are clearly tripartite, vs. quadripartite in C. ornata [Silvestri, 1904; Attems, 1907b, 1938, 1940; Hoffman, 1977; Adis et al., 1998]. Taking into account the particularly profound variations observed in the distribution and location of ozopores within the family Pyrgodesmidae, in which far too many genera, including numerous monotypic ones, are still based on peculiar pore formulae (e.g. Attems [1940]), it would seem tempting to synonymize these two genera as well. However, I suggest first to compare both these species and their genera using molecular evidence. In addition, formal synonymy would inflict numerous taxonomic transfers, as Aporodesminus is older than, and thus has priority over, Cryptocorypha. So let this challenge be deferred for the future.

Considering both new Indochinese species described below, the diversity of described/accepted Cryptocorypha spp. currently amounts to 25 . A key to all of them will conclude the present contribution.

The distribution of Cryptocorypha is basically Old World, largely restricted to the tropics or subtropics, and it covers central and eastern Africa, through Nepal, India, Sri Lanka and Myanmar, to East Asia, southern China, Indochina, western Indonesia, and even Melanesia; one species $(C$. ornata $)$ is particularly widespread, likely due to ornitho- and/or anthropochory introduced 
to several remote islands and archipelagos in the Indian and Pacific oceans [Adis et al., 1998; Golovatch et al., 2017].

\section{A refined diagnosis of Cryptocorypha}

The diagnosis of Cryptocorypha can now be refined as compared to the ones provided recently [Golovatch et al., 2017; Likhitrakarn et al., 2019]:

A genus of small Pyrgodesmidae (4-15 mm long) with a strongly flat body and high paraterga. Adult body with 19 or 20 segments in both sexes, but more usually with 19 segments in $\sigma^{7}$ and 20 segments in $q$. Head usually unmodified, only in several Afrotropical species with a paramedian pair of vertigial humps (only in $\sigma^{7}$ or both in $\sigma^{7}$ and + ). Antennae C-shaped, mostly exposed, antennomere 6 the largest; interantennal isthmus $>1.6$ times as great as diameter of antennal socket. Collum flabellate, fully or almost fully covering the head from above, fore margin regularly convex, not or nearly not lobulated, but with $6+6$ (sub)equal sectors divided by 11 radii; central part usually with two transverse rows of $3+3$ and $2+2$ flat, roundish or transversely oval bosses or low tubercles; sometimes both rows and knobs being vague. Postcollum metaterga each with three transverse rows of regular, non-differentiated, flat bosses or low rounded tubercles partly extending onto paraterga. Lateral margin of postcollum paraterga always indistinctly lobulated, without porosteles: paraterga 2 and 3 invariably trilobate, following ones 3-, 4- or 5-lobate, but poreless paraterga showing fewer lobulations (typically three) than pore-bearing ones (typically four). Anterolateral lobulations absent, but caudolateral ones present (1-3). Tergal setae missing. Pore formula normal $(5,7,9,11,13,15-18(19))$, ozopores inconspicuous, open flush on tergal surface near base of penultimate lateral lobulation. Telson fully exposed in dorsal view, epiproct conical. Last tibia or both last and penultimate tibiae $\left(\sigma^{7}\right.$ and/or + ) often, but not always with an apicodorsal trichostele (= a long tactile seta on stalk or knob).

Gonopods from relatively simple (e.g. C. hoffmani or C. nympha) to complex (e.g. C. diffusa or C. jaegeri sp. n., Figs 9-10), typically clearly transverse; coxae globose, each usually with one or a few strong setae, laterally papillate and microsetose, usually divided by a central sternal tubercle; cannulae unmodified curved tubes; telopodites remaining well-exposed beyond a small to modest gonocoel, each typically tri- or quadripartite, consisting of a distinct mesal solenomere (sl) branch flanked by a more or less prominent, membranous, sometimes ornate, sac- or lobe-shaped, anterolateral velum (v), and a normally long and lateral exomere process $(\mathbf{e x})$. Sometimes both $\mathbf{v}$ and $\mathbf{e x}$ either fully fused into a single sac-shaped structure (C. hoffmani) or $\mathbf{v}$ more or less strongly appressed to ex $(C$. japonica, C. hoffmani, C. stylopus) or en (C. enghoffi), leaving gonopodal telopodite bi- or poorly tripartite. When telopodite clearly quadri- or tripartite, a more or less evident endomere (en) branch normally also distinct (Figs 4-5, 9-10, 17-18).

\section{Descriptions of two new species}

\section{Cryptocorypha bicolorata sp.n.} Figs 1-5.

HOLOTYPE $\sigma^{7}$ (SMF), Laos, Bolakhamsay Prov., Lak Sao,

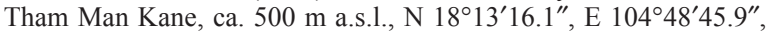
inside cave, 27.II.2012, leg. P. Jäger.

DIAGNOSIS. Differs from other species of the genus by the absence of trichosteles on the last tibiae, combined with a colour pattern, a stout body (length/width ratio ca. 2.4), and the quadripartite gonopodal telopodites (see also Key below).

NAME. To emphasize the bicoloured, brown-and-white pattern.

DESCRIPTION. Length ca. $7.0 \mathrm{~mm}$, width of midbody pro- and metazonae 1.0 and $2.9 \mathrm{~mm}$, respectively. General coloration in alcohol (Figs 1-2) grey-brown, pattern including darker mid-dorsal parts, prozonae and laterad increasingly marbled and light paraterga, as well as distad increasingly infuscate antennae (antennomere 7 darkest, dark brown), whereas most of head and epiproct, anterior $1 / 4$ collum, lateral $1 / 4$ in all following paraterga, caudal margins of all metaterga, sides, venter and legs, all rather contrasting light grey, light brown or nearly pallid, only tips of antennae pallid.

Body with 20 segments. In width, head $<<$ collum $<$ segment $2<3<4=15$; thereafter body rapidly tapering towards telson. Head very densely setose and microgranulate, between and behind antennae on vertex more roughly granulate, mostly dull; epicranial suture superficial, more distinct in vertigial region. Antennae long, slender and very densely setose, only slightly clavate, C-shaped (Fig. 2); in length, antennomere $1=7<2=4<<5<3=6$; antennomere 6 highest, both $5^{\text {th }}$ and $6^{\text {th }}$ with a small, compact, apicodorsal group of minute bacilliform sensilla. Interantennal isthmus ca. 1.8 times as broad as diameter of antennal socket.

Tegument dull dorsally, only legs shining. prozonae and strictures similarly finely shagreened/micro-alveolate. Dorsum very moderately and regularly convex; paraterga mostly set at about upper $1 / 3$ of body, very strongly developed, beginning with collum, regularly declined ventrad much like dorsum (Figs 1-2). Collum flabellate, completely covering the head from above, tauriform, anterior half as usual, flattened, posterior half slightly and regularly elevated, with a few vague, transverse, irregular rows of small, mostly transverse, obliterated tuberculations; anterior margin regularly rounded, with $6+6$ equal sectors. Postcollum paraterga very broad (prozona to metazona width ratio ca. 1:3), flat, only slightly declined ventrad, each much broader than prozona; anterior margin/shoulder always entire, mostly nearly straight and narrowly bordered, increasingly, but faintly curved caudad towards telson, with neither radii nor crenulations; only anterolateral corner slightly rounded. Tergal setae absent. Each poreless or pore-bearing paratergum with three or four subequal lobulations, respectively, along a nearly straight lateral edge, caudal corner drawn increasingly behind rear tergal margin only in segments 17-19; paraterga 19 directed caudad, but slightly shorter than epiproct (Fig. 1). Caudal margins of paraterga increasingly strongly lobulate and radiate laterad, with 1-1.5 lobulations on each side before bases of paraterga, regardless of caudolateral ones (Figs 1-2). 


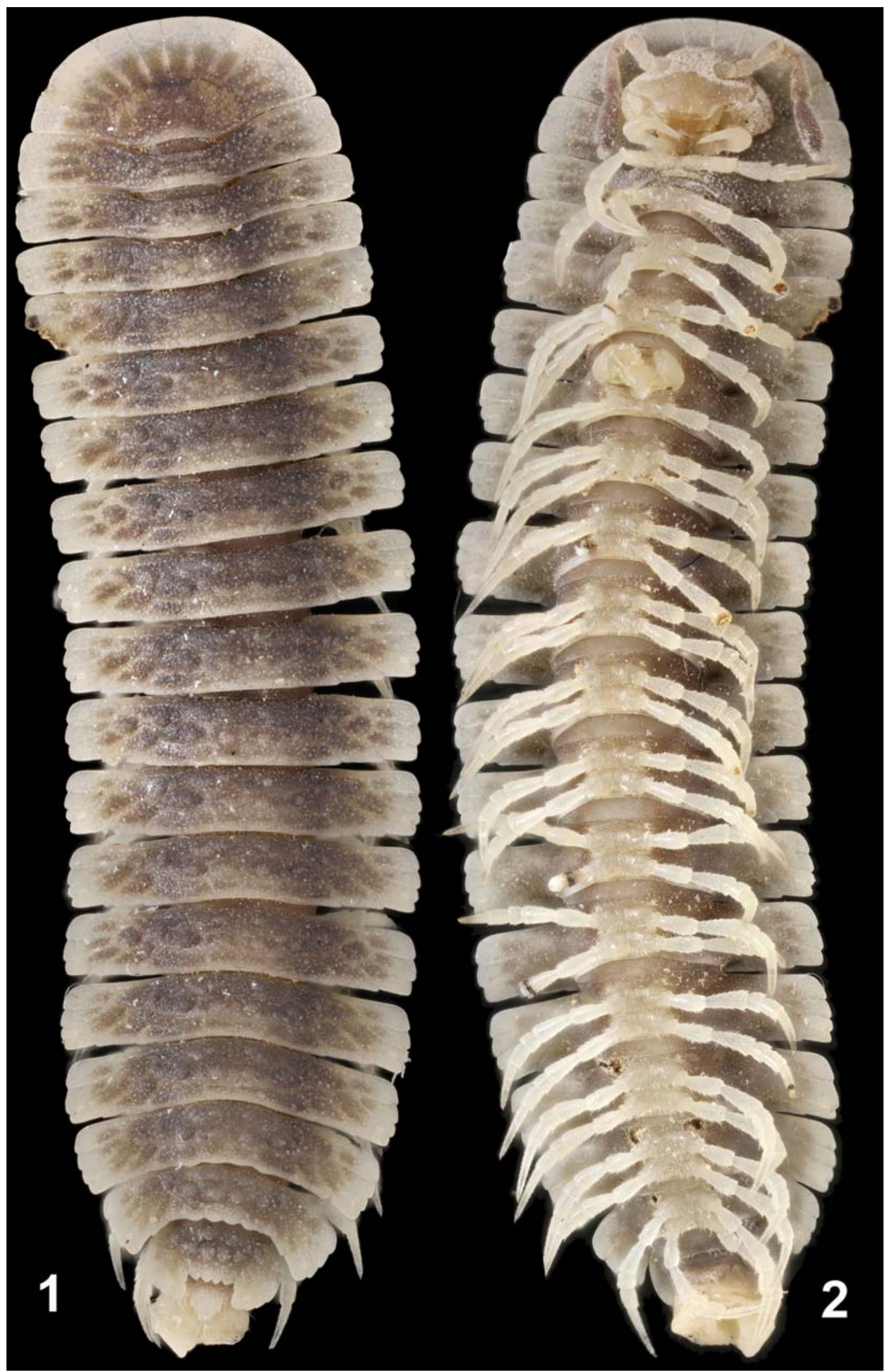

Figs 1-2. Habitus of Cryptocorypha bicolorata sp.n., $\mathrm{O}^{7}$ holotype, dorsal and ventral views, respectively. Pictures by K. Makarov, taken not to scale.

Рис. 1-2. Общий вид Cryptocorypha bicolorata sp.n., голотип O’, соответственно сверху и снизу. Фотографии К. Макарова, сняты без масштаба. 


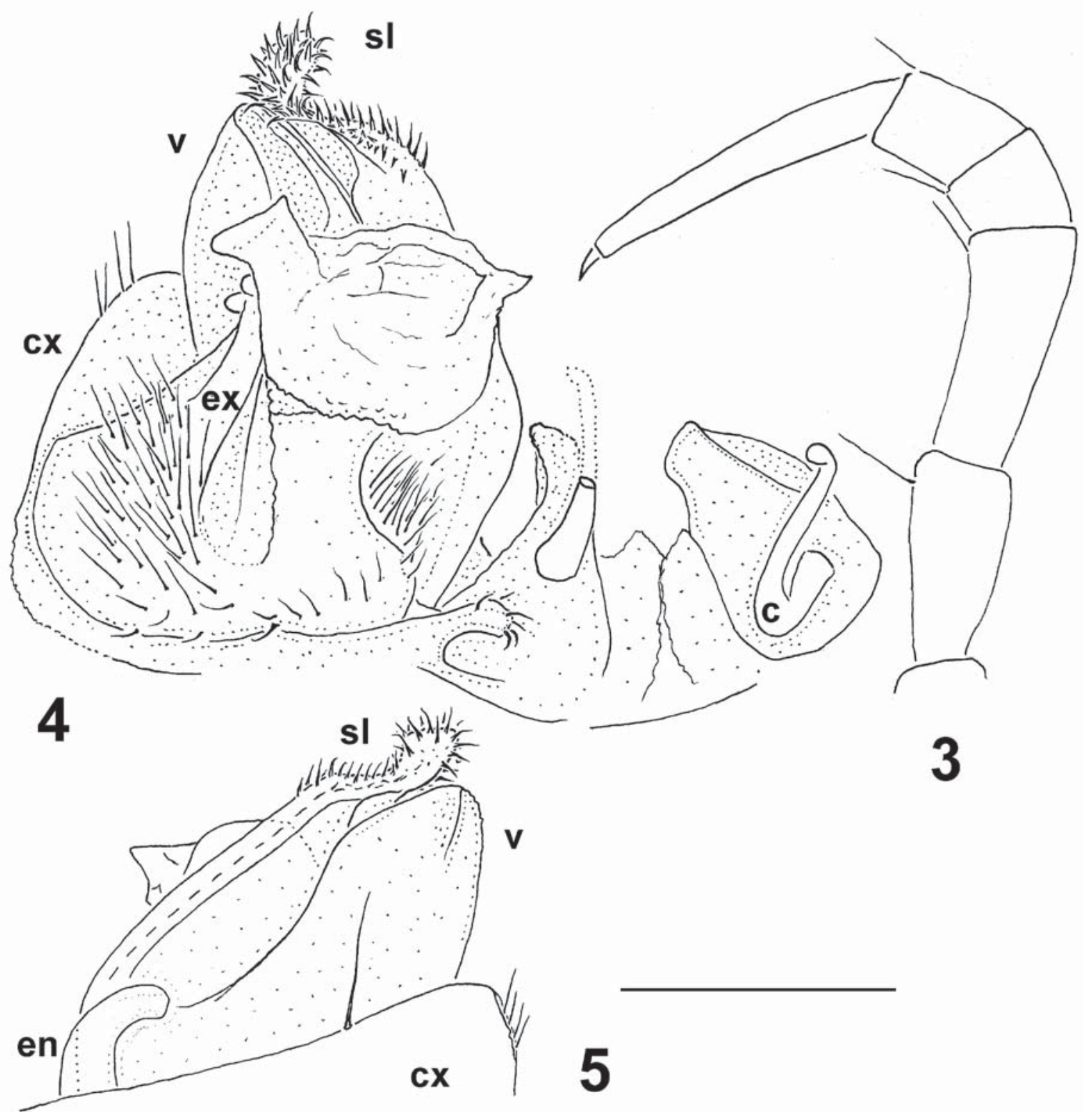

Figs 3-5. Cryptocorypha bicolorata sp.n., $0^{7}$ holotype: $3-\operatorname{leg} 9$, lateral view; 4-5 - right gonopod, mesal and lateral views, respectively. Scale bar: $0.2 \mathrm{~mm}(3), 0.4 \mathrm{~mm}(4-5)$

Abbreviations: c - cannula; cx - coxite; en - endomere; ex - exomere; sl - solenomere; v - velum.

Рис. 3-5. Cryptocorypha bicolorata sp.n., голотип О’: $3-$ нога 9, сбоку; 4-5 - правый гонопод, соответственно изнутри и сбоку. Масштаб: 0,2 мм (3), 0,4 мм (4-5).

Обозначения: c — канюля; сх — коксит; en — эндомер; ex — экзомер; sl — соленомер; v — парус.

Mid-dorsal parts of postcollum metaterga with three transverse and regular rows of small, mostly subtransverse, obliterated, often lighter tubercles/knobs: paramedian $1+1,2+2$ and $2+2$ in anterior, middle and caudal rows, respectively, plus a similar knob near centre of each paratergum. Axial line superficial, about as evident as both sulci dividing the transverse rows of tubercles. Pleurosternal carinae wanting. Pore formula normal, ozopores opening flush dorsally near base of penultimate lobulation of each pore-bearing paratergum. Stricture dividing pro- and metazonae narrow and shallow. Limbus brush-like, very densely microspiculate. Epiproct conical, dorsal and lateral tubercles evident. Hypo- proct subtrapeziform, $1+1$ caudal setae clearly separated, borne on small, but evident knobs.

Sterna very narrow (Fig. 2), densely setose, deeply impressed along main axis. A small, but evident sternal tooth present only near each of coxae 10 and $11\left(\sigma^{7}\right)$ (Fig. 2). Legs long and rather slender (Fig. 3), about as long as paraterga, very densely setose, last tibiae without trichosteles (Fig. 2); in length, tarsi $>$ femora $>$ prefemora $>>$ tibiae $>$ postfemora = coxae; gonapophyses on $\sigma^{7}$ coxae 2 small cones; neither adenostyles nor tarsal brushes. Claws simple, slightly curved ventrad. Gonopod aperture transversely oblong-oval, caudal and lateral margins thin and slightly elevated. 


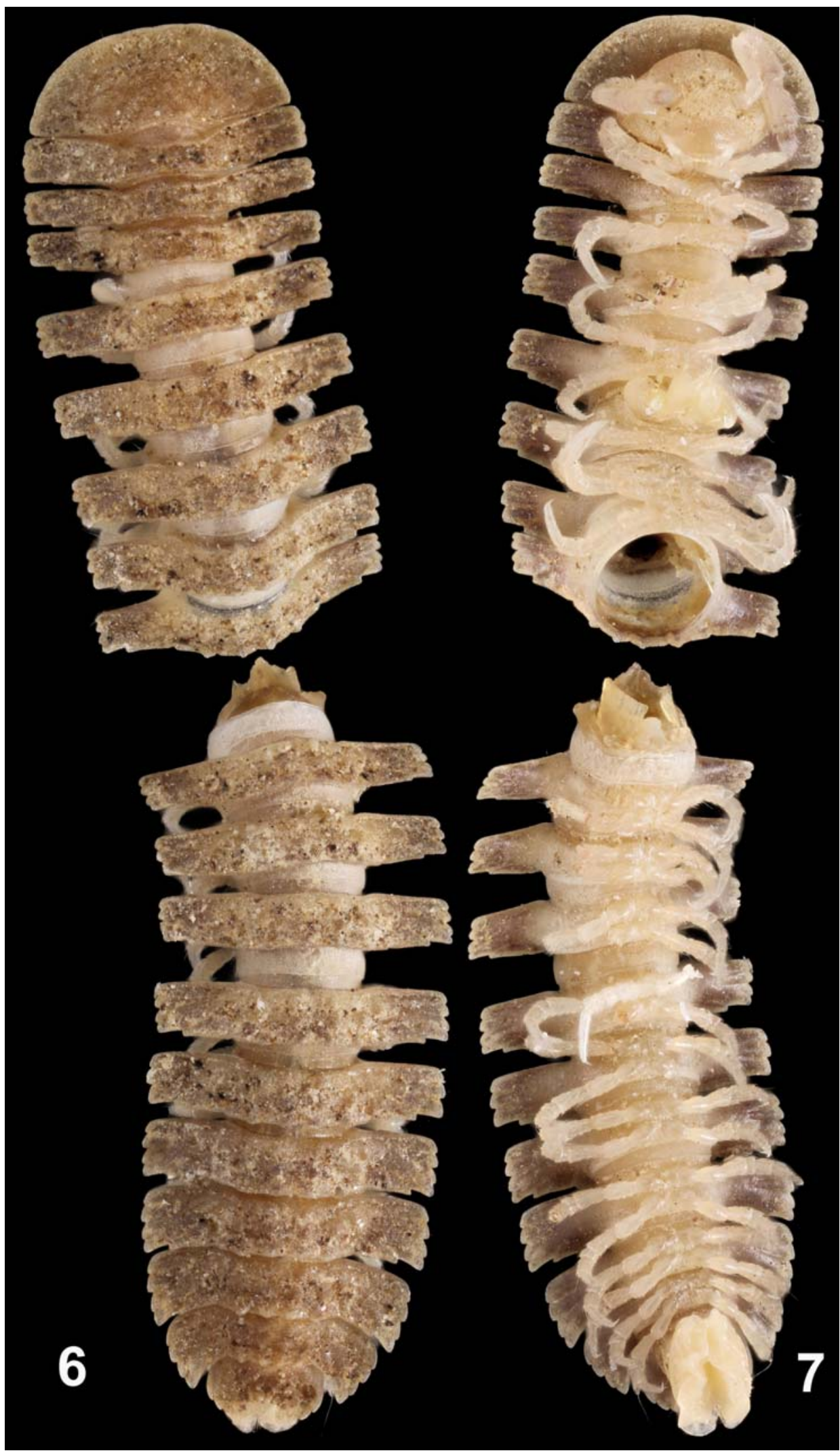

Figs 6-7. Habitus of Cryptocorypha jaegeri sp.n., ơ holotype, dorsal and ventral views, respectively. Pictures by K. Makarov, taken not to scale.

Рис. 6-7. Общий вид Cryptocorypha jaegeri sp.n., голотип О', соответственно сверху и снизу. Фотографии К. Макарова, сняты без масштаба. 


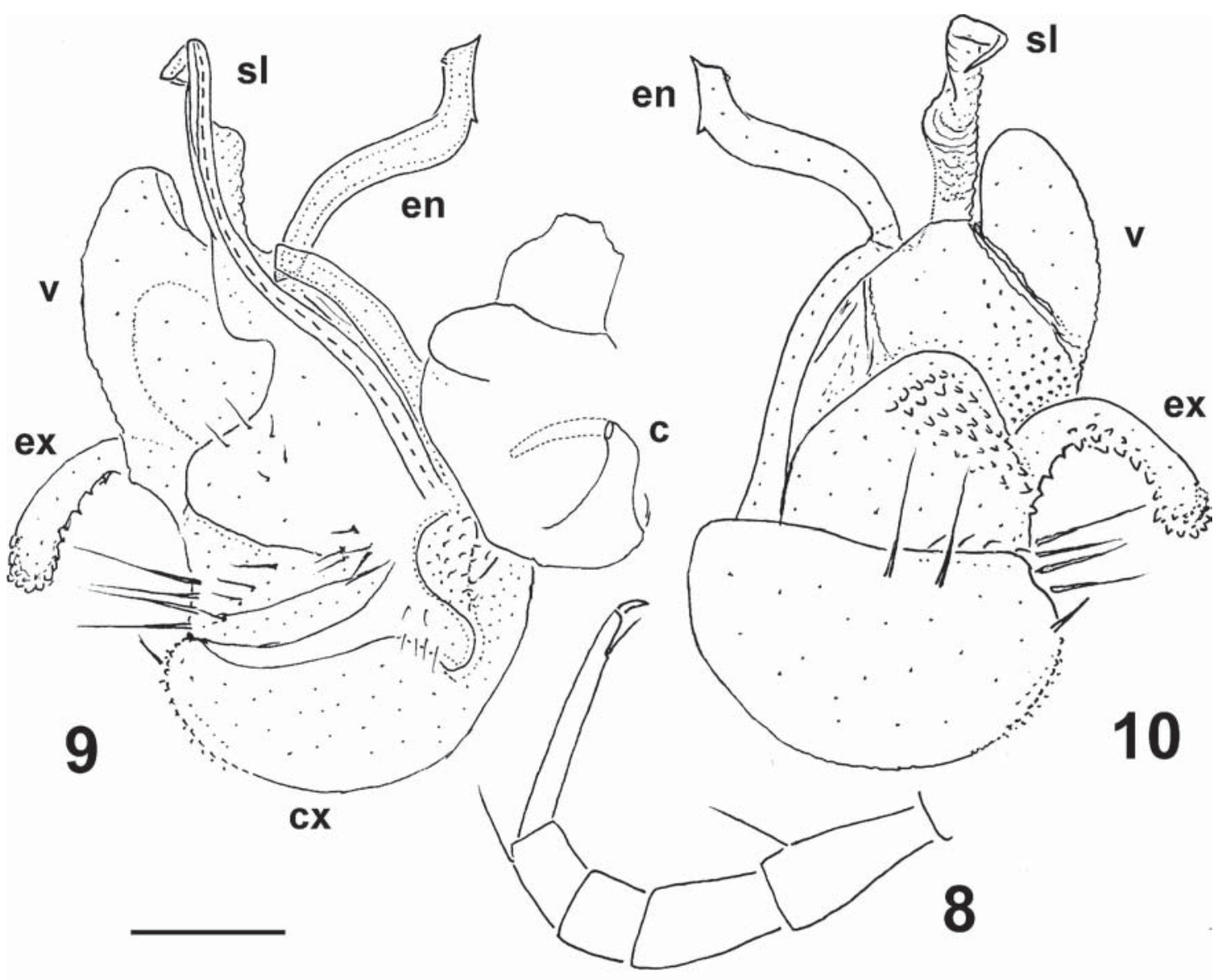

Figs 8-10. Cryptocorypha jaegeri sp.n., $0^{7}$ holotype: $8-\operatorname{leg} 9$, lateral view; 9-10 - right gonopod, mesal and lateral views, respectively. Scale bar: $0.1 \mathrm{~mm}(8), 0.2 \mathrm{~mm}(9-10)$.

Abbreviations: c - cannula; cx - coxite; en - endomere; ex - exomere; sl - solenomere; v - velum.

Рис. 8-10. Cryptocorypha jaegeri sp.n., голотип $0^{7}: 8-$ нога 9, сбоку; 9-10 - правый гонопод, соответственно изнутри и сбоку. Масштаб: 0,1 мм (3), 0,2 мм (4-5).

Обозначения: c — канюля; сx — коксит; en — эндомер; ex — экзомер; sl — соленомер; v — парус.

Gonopods (Figs 4-5) in situ held parallel to each other, complex (Fig. 2). Coxite (cx) relatively large, subtending and concealing basal half of telopodite; cannula (c) as usual. Each telopodite grossly quadripartite and very strongly exposed: a conspicuous, long, ribbon-shaped, acuminate endomere (en) about as high as a slender, distally rugulose, unciform and also acuminate solenomere (sl), followed first by a simple and lower sac-shaped velum (v) and then a relatively short, erect, basally densely setose, rod-shaped, apically vaguely bifid exomere (ex).

REMARK. This is the first Cryptocorypha to be documented from Laos.

\section{Cryptocorypha jaegeri sp.n.}

Figs 6-10.

HOLOTYPE $0^{7}$ (SMF), Thailand, Chiang Mai Prov., W of Chiang Mai, Doi Suthep temple, bus parking area, ca. $1005 \mathrm{~m}$ a.s.l., N $18^{\circ} 48^{\prime} 3.4^{\prime \prime}$, E $98^{\circ} 55^{\prime} 7.8^{\prime \prime}$, daytime, by hand and sifting, 3.VII.2014, leg. P. Jäger.

DIAGNOSIS. This species is distinguished from other species of the genus by the presence of trichosteles on the last tibiae, combined with the quadripartite gonopodal telopodites (see also Key below).

NAME. Honours Peter Jäger (SMF), the collector.

DESCRIPTION. Length ca. $8.0 \mathrm{~mm}$, width of midbody pro- and metazonae 0.9 and $1.9 \mathrm{~mm}$, respectively. General coloration in alcohol (Figs 6-7) marbled rusty brown, but head, antennae, prozonae, strictures, venter, legs, tips of antennae and all margins of collum and following metaterga light grey-yellow or -brown to (nearly) pallid; antennomere 7 contrasting infuscate, brown. lows

All characters as in C. bicolorata sp.n., except as fol-

Antennae a little shorter and stouter, quite clearly clavate (Fig. 6); in length, antennomere $1<2=4=7<<5<3=$ 6. Interantennal isthmus ca. 2.0 times as broad as diameter of antennal socket.

Tegument dull dorsally, metaterga in places with a thin cerotegument crust. prozonae and strictures finely shagreened/ micro-alveolate. Collum in posterior half with a few small, vague and round knobs centrally arranged in 2-3 transverse and irregular rows; anterior margin regularly rounded, with $6+6$ equal and faint sectors. Postcollum paraterga somewhat narrower (prozona to metazona width ratio ca. 1:2), Caudal 
margins of paraterga increasingly strongly lobulate and radiate laterad, with only one lobulation on each side before bases of paraterga, regardless of caudolateral ones (Figs 67). Mid-dorsal parts of postcollum metaterga with three transverse and rather regular rows of small, mostly round tubercles/knobs: paramedian $1+1,2+2$ and $2+2$ in anterior, middle and caudal rows, respectively, plus 1-3 similar knobs near centre of each paratergum; paramedian tubercles usually forming $2+2$ regular serial rows, but axial line missing.

Sternite between coxae 9 somewhat broader than other sterna $\left(\mathrm{O}^{7}\right)$, sternal cones totally missing. Legs shorter and stouter (Fig. 8), prefemora about as long as femora, last tibiae with distinct apicodorsal trichosteles (Fig. 7).

Gonopods (Figs 9-10) quite complex; coxite (cx) typically small, boat-shaped, gonocoel underdeveloped, cannula (c) as usual. Each telopodite grossly quadripartite: a short, ribbon-shaped, curved and apically rounded endomere (en) at base of the longest, distally curved, conspicuously and densely fringed/fimbriate, apically palm-shaped expanded solenomere (sl), followed first by a sac-shaped, mesally irregularly membranous velum (v) and then by a large, clearly papillate/ dentate, gently curved, somewhat clavate exomere (ex).

REMARKS. This is only a second Cryptocorypha, pyrgodesmid and generally micropolydesmid to be reported from Thailand [Likhitrakarn et al., 2019]. There can be no doubt whatever that this is only a miserable fraction of the real diversity of these three groups in Indochina.

\section{Revision of two old species of R.V. Cham- berlin}

As long emphasized elsewhere [Golovatch et al., 2011, 2013; Golovatch, VandenSpiegel 2015], because two old species, C. leia Chamberlin, 1945, from Java, Indonesia and $C$. tobana Chamberlin, 1945, from Sumatra, Indonesia, had been described too poorly [Chamberlin, 1945], no meaningful key to Cryptocorypha spp. could ever be attempted. To finally shed the light on the identities of these two little-known congeners, as well as to be able to finally incorporate them into a key, I have received on loan and revised both relevant holotypes.

\section{Cryptocorypha leia Chamberlin, 1945 Figs 11-13.}

HOLOTYPE $0^{7}$ (AMNH), Indonesia, Java, Goenoeng Malabar, $1600 \mathrm{~m}$, Dec. $20^{\text {th }}, 1920$. The label fully coincides with the one given in the original description [Chamberlin, 1945], the collector(s) remaining unknown.

DESCRIPTIVE REMARKS. The holotype is presently incomplete, fragmented, broken into four pieces (Fig. 11), with the head, collum and segment 7 missing. Based on the last four paraterga being 4-lobulated, the entire number of body segments can be reconstructed as having been $19\left(\mathrm{O}^{7}\right)$. Body width was originally stated as being $2.0 \mathrm{~mm}$ [Chamberlin, 1945]. The last tibia is with an evident trichostele.

All somatic characters are typical, like in most other congeners, including both new species described above.

Gonopod drawings (Figs 12-13) are reproduced from the original description [Chamberlin, 1945]. The telopodites are sunken inside a shallow gonocoel, each telopodite is tripartite, showing two very long, slender, spiniform, simple branches which can be identified as a slightly shorter sole- nomere (sl) and a longer exomere (ex). A sac-shaped velum (v) lies at the base of both sl and ex.

\section{Cryptocorypha tobana Chamberlin, 1945 Figs 14-18.}

HOLOTYPE $\sigma^{7}$ (AMNH), Indonesia, Sumatra, Lake Toba (Tobameer), March 1922. The label does not contain a collector's name, but Chamberlin [1945] attributes it to Dammerman.

DESCRIPTIVE REMARKS. The holotype is complete, presently fragmented, broken into three pieces (Figs 14-16), one of which is an isolated segment 7 with intact gonopods (Fig. 16). Body is with 20 segments $\left(\sigma^{7}\right)$. Body width was originally stated to be $1.2 \mathrm{~mm}$ [Chamberlin, 1945]. The last tibia is with an evident trichostele.

All somatic characters are typical, like in most other congeners, including both new species described above.

Gonopod drawings (Figs 17-18) are reproduced from the original description [Chamberlin, 1945]. The telopodites are sunken inside a shallow gonocoel, each telopodite is tripartite, showing two long branches which can be identified as a slender, flagelliform and apically curved solenomere (sl) and a shorter, subunciform and apically fringed/ fimbriate endomere (en). A sac-shaped velum (v) lies at the base of both sl and en.

\section{A PROVISIONAL KEY TO CRYPTOCORYPHA SPECIES}

The following key must be taken as only provisional, being chiefly based on $\sigma^{7}$ characters, primarily gonopodal ones and using all available literature sources [Attems, 1907a, 1940, 1953; Brolemann, 1920; Carl, 1932; Chamberlin, 1945; Miyosi, 1957; Murakami, 1966; Loksa, 1967; Hoffman, 1977; Zhang, Li, 1981; Golovatch et al., 2011, 2013, 2017; Golovatch, VandenSpiegel, 2015; Golovatch, Martens, 2018; Likhitrakarn et al., 2019]. Given also the records of some already collected, but yet undescribed species and surely a wealth of further Cryptocorypha still to be found, consulting the above, mostly original sources for a secure identification is strongly advised. The number of body segments is of limited use, because too many species still remain known from the $\sigma^{7}$ sex alone. The key holds solely for adults.

1(2) At least $O^{T}$ with 19 segments. Afrotropical species. .. 3 2(1) Either $\sigma^{7}$ alone or both $\sigma^{7}$ and $q$ with 19 or 20 segments. Mostly Asian species. .. 17 3(4) At least $\sigma^{7}$ vertex with a paramedial pair of evident, usually medially separated, but sometimes fused, often more or less mushroom-shaped, squarish or ovoid protuberances. Congo.

4(3) Vertex devoid of protuberances. ............................. 15

5(6) Both vertigial protuberances fused medially into a single, large, squarish tubercle. Subapical lateral process on a very prominent lobe-shaped velum (v) stout, fingershaped and fimbriate....................................... C. coalita

6(5) Both vertigial protuberances clearly separated medially. A subapical lateral process on a similarly large and lobe-shaped or less prominent velum either rather slender and simple or absent.

7(8) Both vertigial protuberances ovoid. Sternal tubercle between gonopodal coxae densely denticulate. Velum somewhat less prominent, not entirely sheathing similarly high 


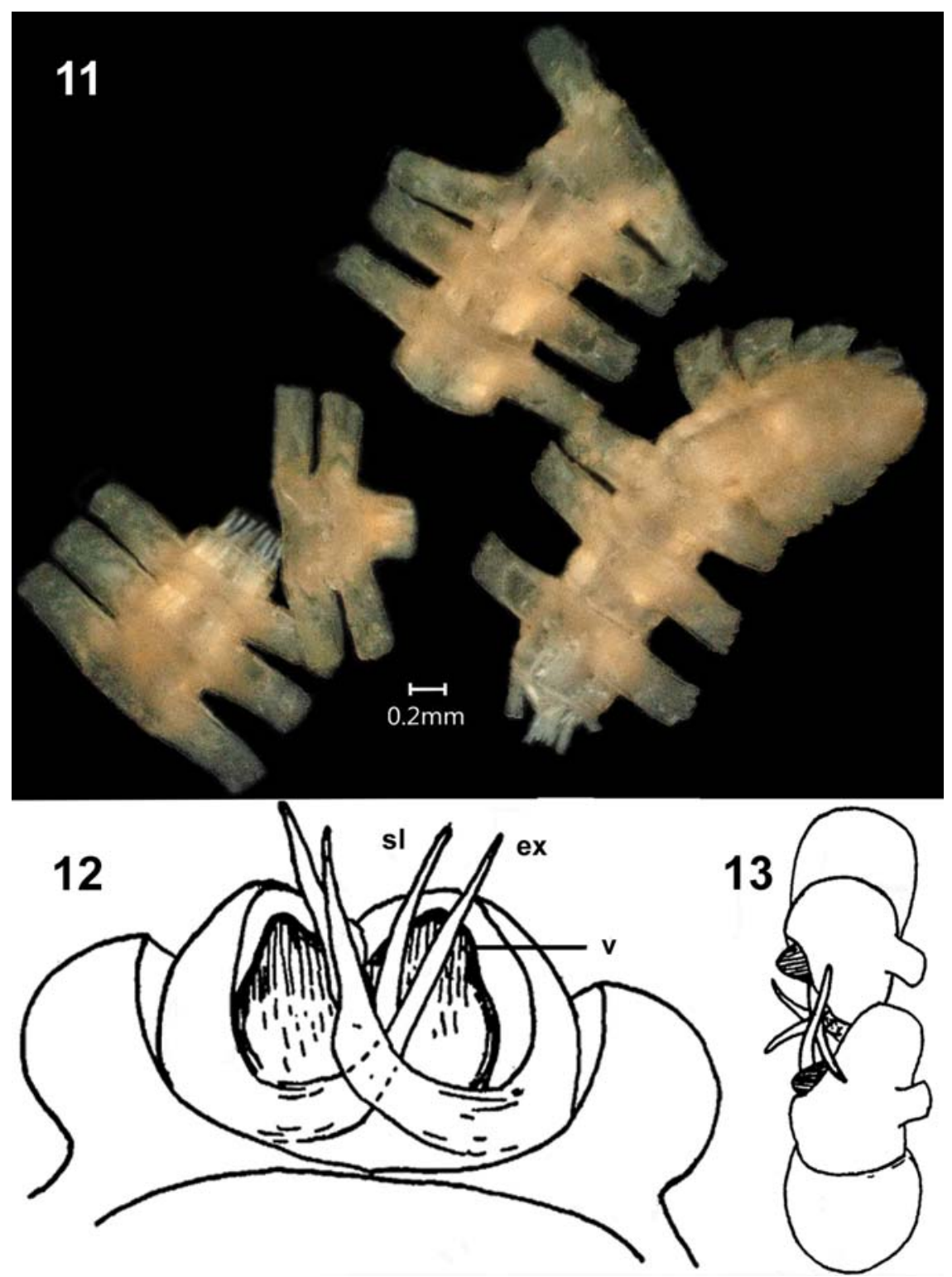

Fig. 11-13. Cryptocorypha leia Chamberlin, 1945, $0^{7}$ holotype: 11 - habitus (remaining body fragments); 12-13 - gonopods in situ, oral and ventral views, respectively. Scale bar: $0.2 \mathrm{~mm}$ (11); reproduced without scale (12-13, after Chamberlin [1945]). Picture 11 taken by Jennifer Trimble.

Abbreviations: ex — exomere; sl — solenomere; $\mathrm{v}$ - velum.

Pис. 11-13. Cryptocorypha leia Chamberlin, 1945, голотип о : 11 - общий вид (оставшиеся фрагменты тела); 12-13 гоноподы на месте, соответственно спереди и снизу. Масштаб: 0,2 мм (11); воспроизведено без масштаба (12-13, по: Chamberlin [1945]). Фотография 11 сделана Jennifer Trimble.

Обозначения: ех — экзомер; sl — соленомер; $\mathrm{v}$ — парус.

and simple solenomere and exomere branches, all these remaining mostly detached from one another; a subapical lateral process on velum absent. ............... C. girafficeps $8(7)$ Both vertigial protuberances mushroom-shaped or ovoid. Sternal tubercle between gonopodal coxae otherwise. Velum (v) prominent, entirely sheathing similarly high and simple solenomere (sl) and exomere (ex) branches; a subapical lateral process on velum either slender or absent.

9(10) Body larger, 8-12 mm long. Both solenomere (sl) and exomere (ex) long and spiniform. Velum (v) very prom- inent, lobe- or ear-shaped. Last tibia without trichostele, instead only a long tactile seta being present. ........... 11

10(9) Body considerably smaller, only 5.5-6.5 mm long. Neither solenomere (sl) nor exomere (ex) spiniform. Velum (v) far less prominent, usually not lobe-shaped. Last tibia with a trichostele, even though supporting stalk small.

11(12) Metatergal tuberculations mostly round. Velum (v) with a characteristic distolateral uncus. ....... C. fungifer

12(11) Metatergal tuberculations mostly transversely oval. Velum (v) devoid of a distolateral outgrowth. .. C. bocal 


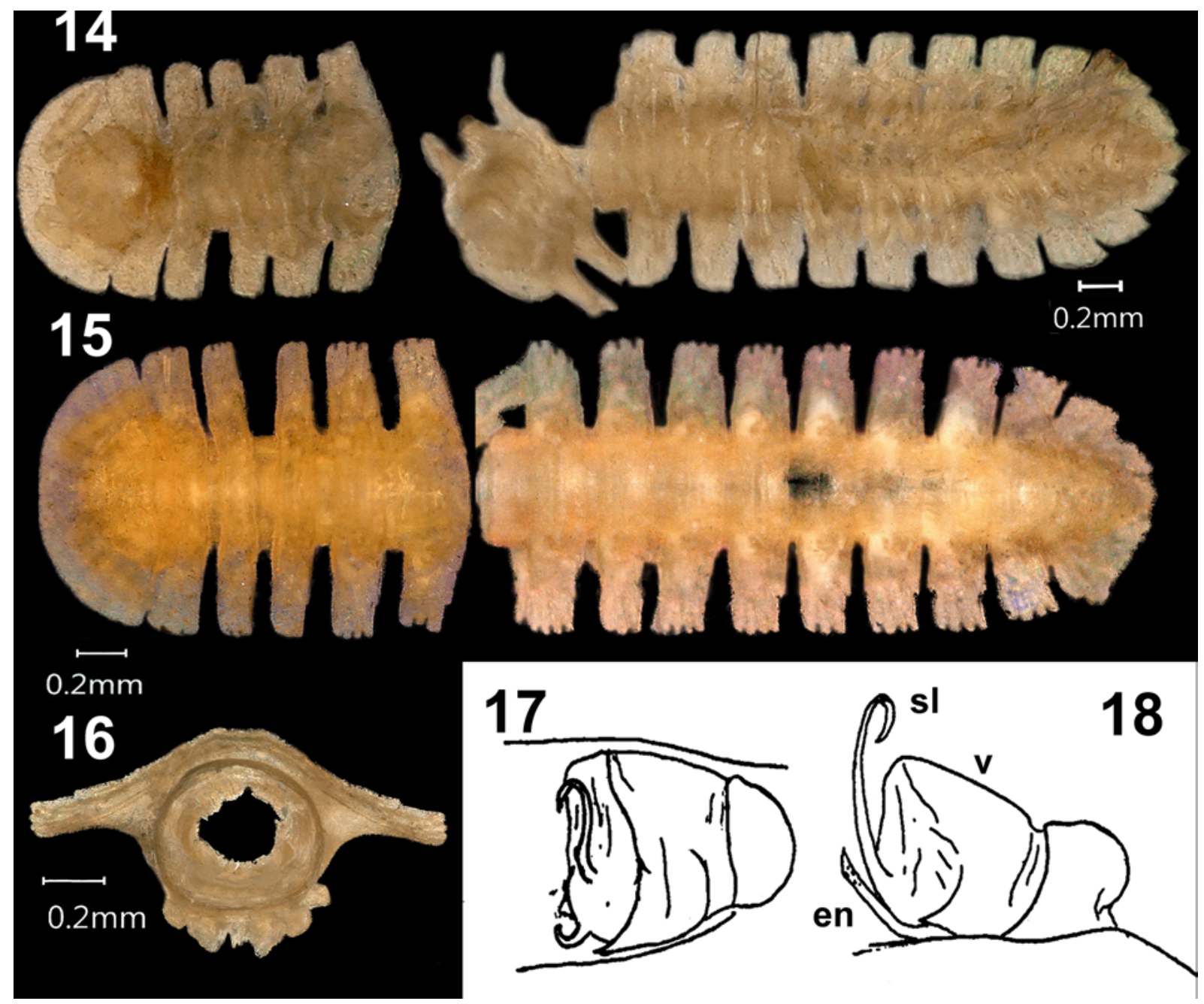

Fig. 14-18. Cryptocorypha tobana Chamberlin, 1945, O' holotype: 14-15 - habitus (remaining body fragments), ventral and dorsal views, respectively; 16 - segment 7 together with gonopods, oral view; 17-18 - right gonopod, ventral and oral views, respectively. Scale bars: $0.2 \mathrm{~mm}$ (14-16); reproduced without scale (17-18, after Chamberlin [1945]). Pictures 14-16 taken by Jennifer Trimble.

Abbreviations: en - endomere; sl - solenomere; $\mathrm{v}$ - velum.

Рис. 14-18. Cryptocorypha tobana Chamberlin, 1945, голотип О: 14-15 - общий вид (оставшиеся фрагменты тела), соответственно снизу и сверху; 17 - сегмент 7 вместе с гоноподами, спереди; 17-18 - правый гонопод, соответственно снизу и спереди. Масштаб: 0,2 мм (14-16); воспроизведено без масштаба (17-18, по: Chamberlin [1945]). Фотографии 14-16 сделаны Jennifer Trimble.

Обозначения: ex — эндомер; sl - соленомер; v — парус.

13(14) Both $\sigma^{7}$ and $q$ with a paramedian pair of vertigial protuberances. Velum longer and slender, exomere $(\mathbf{e x})$ slender. C. monomorpha

14(13) Only $\sigma^{7}$ with a paramedian pair of vertigial protuberances. Velum (v) much shorter, but exomere (ex) prominent, axe-shaped apically. C. dimorpha 15(16) Lateral margin of paraterga 3- or 4-lobulate on poreless and pore-bearing segments, respectively, this being typical of the genus. Gonopods relatively simple, exomere (ex) being the highest branch, solenomere (sl) somewhat shorter, while velum (v) a small lateral lobe. Congo. C. nympha

16(15) Lateral margin of paraterga 3-15 largely 4- or 5lobulate on poreless and pore-bearing segments, respectively. Gonopod relatively complex, exomere (ex) being the longest and especially complex branch, solenomere (sl) relatively short, while velum (v) a prominent, lateral, sac-shaped structure. East Africa (at least Tanzania and Kenya). C. diffusa

17(18) At least $O^{7}$ with 19 segments. Trichostele on last tibia present at least in $\circ$.

19

18(17) Both $\sigma^{7}$ and + with 20 segments. Trichostele on last tibia present or absent..... 23

19(20) Larger: length 9-10 mm, width ca. $2.0 \mathrm{~mm}$. Gonopodal telopodite tripartite, with two very long, slender, spiniform, simple branches: a shorter solenomere (sl) and a longer exomere (ex); a sac-shaped velum (v) at base of both sl and ex (Figs 12-13). Java, Indonesia.... C. leia

20(19) Smaller: length $8 \mathrm{~mm}$, width $1.3 \mathrm{~mm}$. Gonopodal telopodite tri- or quadripartite, shapes of outgrowths otherwise. 
21(22) Smaller: length $4.5-5 \mathrm{~mm}$, width $0.5-0.6 \mathrm{~mm}$. Gonopodal telopodite tripartite: sl bifid, ex long and thick, with a retrose acuminate apex, $\mathbf{v}$ the highest, irregularly sac-shaped, with a flagelloid at base on medial face. Vanuatu, Melanesia. C. chernovi

22(21) Larger: length 5-8 mm, width 1.1-1.3 mm. Gonopodal telopodite quadripartite: sl the longest, apically spinulose, only a little longer than subequally high, a prominent sac-shaped $\mathbf{v}$, a slender en, and a spinulate ex, the latter either tightly attached or largely fused to v. Java, Indonesia. C. stylopus

23(24) Among the smallest: length 4-4.5 mm. Trichostele on last tibia absent. Gonopodal telopodite bipartite: a short, papillate, rod-shaped, subtruncate sl fully concealed by a hypertrophied, setose telopodite $+\mathbf{v}$. Southern Vietnam.

C. hoffmani

24(23) Usually larger. Trichostele on last tibia present or absent. Gonopodal telopodite tri- or quadripartite. ... 25

25(26) Among the largest: length $10 \mathrm{~mm}$, width $1.9 \mathrm{~mm}$.

26(25) Smaller. ................................................................... 31

27(28) The largest: length $12-15 \mathrm{~mm}$, width $2.6-3.4 \mathrm{~mm}$. Gonopodal telopodite quadripartite: sl the highest, as slender as a slightly shorter and closely appressed en; ex short and tuberculate-spinulate, $\mathbf{v}$ a low and small lobe. Northern Thailand.

28(27) Smaller. Gonopodal telopodite tri- or quadripartite, in any case all outgrowths shaped otherwise. ............ 29

29(30) Length 10-11 mm, width 1.9-2.0 mm. Trichostele on last tibia present. Gonopodal telopodite quadripartite, with the highest and slender sl, somewhat lower and subequally long ex (densely spiculate) and en, and a low and simple $\mathbf{v}$ with a short, laterobasal, spiculate stump. Myanmar. C. perplexa

30(29) Length 9-12, width 2.4-2.5 mm. Trichostele on last tibia absent. Gonopodal telopodite tripartite: $\mathbf{v}$ hypertrophied, sac-shaped, apically rounded, a little higher than an apically plumose sl and much higher than a short, apically spiculate ex. Guangxi, southern China.

C. spinicoronata

31(32) Trichostele on last tibia absent. ............................ 33

32(31) Trichostele on last tibia present. ............................. 41

33(34) Body stouter: length $7 \mathrm{~mm}$, width $2.9 \mathrm{~mm}$, i.e. length/ width ratio ca. 2.4 (Figs 1-2). Gonopodal telopodite quadripartite: a conspicuous, long, ribbon-shaped, acuminate en about as high as a slender, distally rugulose, unciform and also acuminate sl, followed first by a simple and lower sac-shaped $\mathbf{v}$ and then a relatively short, erect, basally densely setose, rod-shaped, apically vaguely bifid ex (Figs 4-5). Laos. ................ C. bicolorata sp.n.

34(33) Even when length comparable, body considerably more slender. Gonopodal telopodite tri- or quadripartite, but shapes of outgrowths otherwise

35 (36) Length $8-10 \mathrm{~mm}$, width $1.6-1.8 \mathrm{~mm}$. Gonopodal telopodite tripartite: both sl and ex bifid and somewhat shorter that a hypertrophied $\mathbf{v}$ with an anterolateral outgrowth. Southern India......................... C. tuberculata

36(35) Body smaller, length 5-6 mm, width $1.2-1.3 \mathrm{~mm}$. Gonopodal telopodite tri- or quadripartite, but shapes of outgrowths otherwise..................................................... 37

37(38) Gonopodal telopodite quadripartite: an apically plumose and slender sl only very slightly higher than a very prominent and densely spiculate $\mathbf{v}$ and a distomesally slightly spinulate and slender en, while ex a curved, thick, distally denticulate, lateral process. Nearly pantropical.
38(37) Gonopodal telopodite tri- or quadripartite. .......... 39

39(40) sl the longest, ribbon-shaped, papillate and acuminate, only a little longer than a voluminous, squarish, densely papillate/granulate $\mathbf{v}$ and much longer than a curved and denticulate ex. Kyushu, Japan.

C. kumamotensis

40(39) sl the longest, apically branching and plumose; both en and $\mathbf{v}$ subequal in height, medium-sized, 2/3 as high as sl. Sri Lanka. C. kandyana

41(42) Larger: length 8-10 mm, width 1.6-1.9 mm. Gonopodal telopodite quadripartite: a short, ribbon-shaped, curved and apically rounded en at base of the longest, distally curved, conspicuously and densely fringed/fimbriate, apically palm-shaped sl, followed first by a sacshaped, mesally irregularly membranous $\mathbf{v}$ and then by a large, clearly papillate/dentate, gently curved, somewhat clavate ex (Figs 9-10). Northern Thailand. C. jaegeri sp.n.

42(41) Smaller: length 4-6 mm. width 0.7-1.2 mm. Gonopodal telopodite tripartite. ............................................ 46

43(44) Postcollum metaterga clearly areate. Gonopodal telopodite: sl the highest and plumose apically, ex spiculate, and $\mathbf{v}$ high and sac-shaped. Southern India.

$$
\text { C. areata }
$$

44(43) Postcollum metaterga tubercolate, areations, if any, vague. Gonopodal telopodite otherwise..................... 45

45(46) Gonopodal telopodites unusually slender and elongate, sl the longest, simple; $\mathbf{v}$ a high round lobe, only a little lower than sl; ex strong, papillate and anchoriform, somewhat shorter than $\mathbf{v}$. Southern India and Mauritius. C. riparia

46(47) Gonopodal telopodites clearly transverse and stout, outgrowths otherwise............................................... 48

48(49) Two branches particularly long: a slender, flagelliform and apically curved sl and a shorter, subunciform and apically fringed/fimbriate en, with a sac-shaped $\mathbf{v}$ at base of both (Figs 17-18). Sumatra, Indonesia.

.. C. tobana

49(48) sl the longest, strongly plumose/fimbriate in distal half; both a voluminous sac-shaped $\mathbf{v}$ and a distally denticulate and tightly appressed ex subequal in height. Tokyo, Japan. C. japonica

\section{Acknowledgements}

Special thanks go to Peter Jäger and Julia Altmann (both SMF) for inviting me to work for a month at the SMF in July and August 2018, as well as for rendering me for study the material of two new Cryptocorypha species under their care. Lorenzo Prendini and Pio Colminares (both AMNH) kindly arranged for me on loan the types of two Cryptocorypha species of R.V. Chamberlin from the AMNH collection. These two types were revised, and the necessary pictures taken, at the MCZ through the generous help and technical assistance of Gonzalo Giribet, Adam J. Baldinger and Jennifer Trimble (all MCZ). I am also obliged to Kirill Makarov (Moscow, Russia) and again to Jennifer Trimple (MCZ, USA) for the help in taking and stacking the colour pictures.

\section{References}

Adis J., Golovatch S.I., Hoffman R.L., Hales D.F., Burrows F.J. 1998. Morphological adaptations of the semiaquatic millipede Aporodesminus wallacei Silvestri, 1904 with notes on the taxonomy, distribution, habitats and ecology of this and a related species (Pyrgodesmidae, Polydesmida, Diplopoda) // 
Tropical Zoology. Vol.11. P.371-387. doi: 1080/03946975. 1998.10539372

Attems C. 1907a. Javanische Myriopoden, gesammelt von Direktor Dr. K. Kraepelin im Jahre 1903 // Mitteilungen aus dem Naturhistorischen Museum in Hamburg. Bd.24. S.77-142. https:// biodiversitylibrary.org/page/10278476

Attems C. 1907b. Die Myriopoden der Deutschen Südpolar-Expedition 1901-1903 // von Drygalski E. (Hrsg.). Deutsche Südpolar-Expedition 1901-1903. Berlin. Bd.9. Zoologie I. Band. S.417-433.

Attems C. 1912. Myriopoden // Schubotz H. (Hrsg.). Wissenschaftliche Ergebnisse der Deutschen Zentral-Afrika-Expedition 19071908 unter Führung Adolf Friedrichs, Herzogs zu Mecklenburg. Bd.4. Zoologie II. Lfg.10. S.297-324.

Attems C. 1938. Myriopoden von Hawaii // Proceedings of the Linnean Society of London. Vol.108B. P.365-387.

Attems C. 1940. Myriapoda 3. Polydesmidea III. Fam. Polydesmidae, Vanhoeffeniidae, Cryptodesmidae, Oniscodesmidae, Sphaerotrichopidae, Peridontodesmidae, Rhachidesmidae, Macellolophidae, Pandirodesmidae // Das Tierrerich. Lfg.70. S.i-xvii $+1-577$.

Attems C. 1953. Neue Myriopoden des Belgischen Congo // Annales du Musée Royal du Congo belge, Tervuren, série in $8^{\circ}$, sciences zoologiques. T.18. P.1-138.

Brolemann H.W. 1920. Myriapodes III. Diplopoda // Shultz A. (ed.). Voyage de Ch. Alluaud et R. Jeannel en Afrique Orientale (1911-1912). Résultats scientifiques. Librairie des Sciences Naturelles Léon Lhomme, Paris. P.49-298. https:// biodiversitylibrary.org/page/56511877

Carl J. 1932. Diplopoden aus Süd-Indien und Ceylon. 1. Teil. Polydesmoidea // Revue suisse de Zoologie. T.39. Fasc.17. P.411-529. doi.org/10.5962/bhl.part.118948

Chamberlin R.V. 1945. On some diplopods from the Indo-Australian Archipelago // American Museum Novitates. No.1272. P.1-42.

Golovatch S.I., Martens J. 2018. Distribution, diversity patterns and faunogenesis of the millipedes (Diplopoda) of the Himalayas // ZooKeys. Vol.741. P.3-34. doi.org/10.3897/zookeys.741.20041

Golovatch S.I., VandenSpiegel D. 2015. A new species of the millipede genus Cryptocorypha Attems, 1907, from Myanmar (Diplopoda: Polydesmida: Pyrgodesmidae) // Arthropoda Selecta. Vol.24. No.1. P.27-31.

Golovatch S.I., Geoffroy J.-J., VandenSpiegel D. 2013. A new species of the millipede genus Cryptocorypha Attems, 1907, from Vanuatu, Melanesia, southwestern Pacific (Diplopoda: Polydesmida: Pyrgodesmidae) // Arthropoda Selecta. Vol.22. No.4. P.333-337.

Golovatch S.I., Nzoko Fiemapong A.R., VandenSpiegel D. 2017. Notes on Afrotropical Pyrgodesmidae, 3 (Diplopoda: Polydesmida) // Arthropoda Selecta. Vol.26. No.3. P.175-215.

Golovatch S.I., Semenyuk I.I., VandenSpiegel D., Anichkin A.E. 2011. Three new species of the millipede family Pyrgodesmidae from Nam Cat Tien National Park, southern Vietnam (Diplopoda: Polydesmida) // Arthropoda Selecta. Vol.20. No.1. P.1-9.

Hoffman R.L. 1977. Diplopoda // La faune terrestre de l'île de Sainte-Hélène, Musée Royal de l'Afrique centrale, Tervuren, série in-8. No.220. Partie 4. P.360-377.

Hoffman R.L. 1980. Classification of the Diplopoda. Genève: Muséum d'histoire naturelle. 237 p. (for 1979).

Likhitrakarn N., Golovatch S.I., Srisonchai R., Sutcharit C., Panha S. 2019. A new species of the millipede genus Cryptocorypha Attems, 1907, from northern Thailand (Polydesmida, Pyrgodesmidae) // ZooKeys. Vol.833. P.121-132. https://doi.org/ 10.3897/zookeys. 833.32413

Loksa I. 1967. The Scientific Results of the Hungarian Soil Zoological Expedition to the Brazzaville-Congo. 32. Diplopoda, I // Opuscula Zoologica, Budapest. T.7. Fasc.2. P.205-220. http:// opuscula.elte.hu/PDF/Opuscula7_1/Loksa,\%20I 7 1110.pdf

Miyosi Y. 1957. [Beiträge zur Kenntnis japanischer Myriopoden. 19. Aufsatz: Über eine neue Gattung und zwei neue Arten von Diplopoden] // Zoological Magazine. Vol.66. No.1. P.29-33 [in Japanese with German abstract].

Murakami Y. 1966. [Postembryonic development of the common Myriapoda of Japan. XXI. A new genus of the family Oniscodesmidae and a new species of the genus Archandrodesmus (Cryptodesmidae)] // Zoological Magazine. Vol.75. No.2. P.3033 [in Japanese with English abstract].

Silvestri F. 1904. Myriopoda // Fauna Hawaiiensis. Vol.3. P.323338.

Verhoeff K.W. 1941. Diplopoden der Insel Mauritius und ihre zoogeographische Bedeutung // Jenaische Zeitschrift für Naturwissenschaft. Bd.73. S.37-96.

Zhang C.Z., Li Z.Y. 1981. [Eine neue Art vom Archandrodesmus (Cryptodesmidae, Diplopoda) aus China] // Acta Zootaxonomica Sinica. Vol.63. P.250-252 [in Chinese with German abstract].

Responsible editor K.G. Mikhailov 